\title{
Constraints Faced by the Mango Growers in Adoption of Plant Protection Measures
}

\author{
Sayali V. Thakur' ${ }^{1}$ V. S. Shirke ${ }^{2}$ \\ ${ }^{1}$ M. Sc. (Agri.) Student, Division of Agricultural Extension, College of Agriculture, Pune- 410005 \\ ${ }^{2}$ Professor, Division of Agricultural Extension, College of Agriculture, Pune- 410005
}

\begin{abstract}
The study revealed that lack of technical and scientific guidance regarding plant protection measures, lack of knowledge regarding quantity and concentrations of chemicals to be used and lack of knowledge regarding identification of pests, their nature of damage, diseases and their symptoms, unavailability of required insecticides and fungicides at village level, high cost of plant protection chemicals and equipments, unavailability of plant protection equipments on hire basis, lack of facilities for repairing plant protection equipments at village level, lack of finance and sudden rainfall after spraying causes washing off plant protection were the major constraints faced by the mango growers.
\end{abstract}

Keywords: Constraints, Mango, Plant Protection

\section{Introduction}

India is endowed with diverse agro-climate and soil type which is unique advantage for a wide range of horticultural crops. Mango (Mangifera indica L.) belonging to family Anacardiaceae is the world's leading fru it crop and it is the second most important commercially grown fruit crop of the country after banana. Total mango production in India is 18.00 million tonnes with 22.1 per cent share in total fruit production. Irrespective to the reality that India is having a comparative advantage over other mango producing countries in terms of total production still the productivity (7.2 tonnes/ha) continues to be low. Maharashtra is one of the major states in case of area under mango ( 0.48 million ha) but total mango production of the state is low as compared to other states ( 0.63 million tonnes). Hence, productivity of mango in Maharashtra is tends to be very low (1.3 tonnes/ha). (Indian Horticulture Database 2013)

As mango is susceptible to incidence of different pests and diseases, their occurrence is the important factor influencing its production and productivity. The loss of yield in mango is due to occurrence of different pest and diseases and inability to control the same by the growers due to lack of knowledge. Generally, it is observed that mango growers do not adopt plant protection measures on large scale, which is one of the main hindrances in increasing productivity. Hence this paper aims at understanding constraints faced by the mango growers in adoption of recommended plant protection measures and suggestions made by them to overcome these constraints.

\section{Methodology}

Kolhapur district of western Maharashtra region which is adjacent to the leading region in mango production i.e. South Konkan was selected purposively. Two tehsils from Kolhapur district viz; Chandgad and Gadhinglaj with highest area under mango crop were selected. Information regarding the progressive mango growers was obtained from the Taluka Agriculture Officer and then 105 respondents from two tehsils were selected purposively considering the conveyance and objectives of the study.

\section{Result and Discussion}

Constraints faced by the mango growers in adoption of recommended plant protection measures

The data mentioned in Table 1 revealed that regarding knowledge of the plant protection measures, major constraints faced by the mango growers were " lack of technical and scientific guidance regarding plant protection measures' (90.48\%), 'lack of knowledge regarding quantity and concentrations of chemicals to be used' ( 84.76 $\%)$, whereas 'lack of knowledge regarding identification of pests, their nature of damage, diseases and their symptoms' was also important constraint faced by 78.10 per cent of the respondents.

Table 1: Constraints faced by the mango growers in adoption of recommended plant protection measures

\begin{tabular}{|c|c|c|c|}
\hline \multirow{2}{*}{$\begin{array}{l}\text { Sr. } \\
\text { No }\end{array}$} & \multirow{2}{*}{ Constraints } & \multicolumn{2}{|c|}{$\begin{array}{l}\text { Respondents, } \mathrm{n}= \\
105\end{array}$} \\
\hline & & Number & Percent \\
\hline \multicolumn{4}{|c|}{$\begin{array}{l}\text { I } \begin{array}{l}\text { Constraints regarding knowledge of plant protection } \\
\text { measures }\end{array} \\
\text { a }\end{array}$} \\
\hline 1 & $\begin{array}{l}\text { Lack of technical and scientific guidance } \\
\text { regarding plant protection measures }\end{array}$ & 95 & 90.48 \\
\hline 2 & $\begin{array}{l}\text { Lack of knowledge regarding quantity and } \\
\text { concentrations of chemicals to be used }\end{array}$ & 89 & 84.76 \\
\hline 3 & $\begin{array}{l}\text { Lack of knowledge regarding } \\
\text { identification of pests, their nature of } \\
\text { damage, diseases and their symptoms }\end{array}$ & 82 & 78.10 \\
\hline II & \multicolumn{3}{|c|}{$\begin{array}{l}\text { Constraints regarding plant protection chemicals and } \\
\text { equipments }\end{array}$} \\
\hline 1 & $\begin{array}{l}\text { Unavailability of required insecticides and } \\
\text { fungicides at village level }\end{array}$ & 87 & 82.86 \\
\hline 2 & $\begin{array}{l}\text { High cost of plant protection chemicals } \\
\text { and equipments }\end{array}$ & 73 & 69.52 \\
\hline 4 & $\begin{array}{l}\text { Unavailability of plant protection } \\
\text { equipments on hire basis }\end{array}$ & 69 & 65.71 \\
\hline 6 & $\begin{array}{l}\text { Lack of facilities for repairing plant } \\
\text { protection equipments at village level }\end{array}$ & 65 & 61.90 \\
\hline \multicolumn{4}{|c|}{ III Other constraints } \\
\hline 1 & Lack of finance & 45 & 49.52 \\
\hline 2 & $\begin{array}{l}\text { Sudden rainfall after spraying causes } \\
\text { washing off plant protection chemicals }\end{array}$ & 13 & 12.38 \\
\hline
\end{tabular}




\section{International Journal of Science and Research (IJSR) \\ ISSN (Online): 2319-7064 \\ Index Copernicus Value (2013): 6.14 | Impact Factor (2015): 6.391}

In case of constraints regarding plant protection chemicals and equipments, 'unavailability of required insecticides and fungicides at village level' was the most frequent constraint faced by 82.86 per cent of the respondents followed by 'high cost of plant protection chemicals and equipments' (69.52 $\%)$, 'unavailability of plant protection equipments on hire basis' $(65.71 \%)$ and 'lack of facilities for repairing plant protection equipments at village level' (61.\%).

Other important constraints faced by the mango growers were 'lack of finance' (49.52\%) and 'sudden rainfall after spraying causes washing off plant protection chemicals' (12.38 \%).
Suggestions made by the mango growers to overcome the constraints in adoption of plant protection measures

It can be depicted from data presented in Table 2 that the major suggestions made by the mango growers to overcome constraints regarding knowledge of plant protection measures were 'information regarding recommended doses of insecticides and fungicides should be given by expert personnel at village level' (85.71\%), 'training should be organized more often at village level for mango growers regarding identification of pests, their nature of damage, diseases and their symptoms' (80.95\%), 'information about recommended plant protection measures should be displayed at public places' (34.28 \%) and 'need to establish good linkages between farmers and research system for proper guidance' (22.86\%).

Table 2: Suggestions made by the mango growers to overcome the constraints in adoption of plant protection measures

\begin{tabular}{|c|c|c|c|c|}
\hline \multirow{2}{*}{ Sr. No. } & \multirow{2}{*}{\multicolumn{2}{|c|}{ Suggestions }} & \multicolumn{2}{|c|}{ Respondents, $\mathrm{n}=105$} \\
\hline & & & Number & Percent \\
\hline I & \multicolumn{4}{|c|}{ Suggestions regarding knowledge of plant protection measures } \\
\hline 1 & \multicolumn{2}{|c|}{$\begin{array}{c}\text { Information regarding recommended doses of insecticides and fungicides should be given by expert } \\
\text { personnel at village level }\end{array}$} & 90 & 85.71 \\
\hline 2 & \multicolumn{2}{|c|}{$\begin{array}{c}\text { Training should be organized more often at village level for mango growers regarding identification of } \\
\text { pests, their nature of damage, diseases and their symptoms }\end{array}$} & 85 & 80.95 \\
\hline 3 & \multicolumn{2}{|c|}{ Information about recommended plant protection measures should be displayed at public places } & 36 & 34.28 \\
\hline 4 & \multicolumn{2}{|c|}{ Need to establish good linkages between farmers and research system for proper guidance } & 24 & 22.86 \\
\hline II & \multicolumn{4}{|c|}{ Suggestions regarding plant protection chemicals and equipments } \\
\hline 1 & \multicolumn{2}{|c|}{ Insecticides and fungicides should be made available on time at village level } & 87 & 82.86 \\
\hline 2 & Cost of plant protection chemicals and equipments should be re & & 73 & 69.52 \\
\hline 3 & \multicolumn{2}{|c|}{ Plant protection equipments of high cost should be made available on hire basis at village level } & 65 & 61.90 \\
\hline 4 & \multicolumn{2}{|c|}{ Facilities for repairing plant protection equipments should be provided at village level } & 65 & 61.90 \\
\hline III & \multirow{2}{*}{\multicolumn{2}{|c|}{ Other suggestions }} & & \\
\hline 1 & & & 45 & 42.85 \\
\hline 2 & \multicolumn{2}{|c|}{ Outbreak weather situations should be forecasted regularly through newspaper or TV channel } & 13 & 12.38 \\
\hline 3 & $\begin{array}{ll}\text { Establishment of Agri- clinic at village level } \\
\end{array}$ & $x^{2}$ & 5 & 04.76 \\
\hline
\end{tabular}

To overcome the constraints regarding plant protection chemicals and equipments, 82.86 per cent of the mango growers suggested that 'insecticides and fungicides should be made available on time at village level', whereas other suggestions given by them were 'cost of plant protection chemicals and equipments should be reduced' (69.52\%), 'plant protection equipments of high cost should be made available on hire basis at village level' $(61.90 \%)$ and 'facilities for repairing plant protection equipments should be provided at village level' (61.90\%).

The important suggestions made by the mango growers were 'financial support should be provided by the government' (42.85\%), 'outbreak weather situations should be forecasted regularly through newspaper or TV channel' (12.38\%) and 'establishment of Agri- clinic at village level' (04.76\%).

\section{Conclusion}

The study revealed that mango growers are facing major constraints related to knowledge of plant protection measures, as well as regarding plant protection chemicals and equipments hence Agricultural Universities and State Department of Agriculture should provide proper scientific and technical guidance regarding recommended plant protection measures of mango through trainings under different human resource development programmes at block as well as at village level. Integrated pest and disease management measures should be undertaken by the mango growers and accordingly extension agency should give more emphasis on this aspect. Demonstrations regarding plant protection measures should be undertaken by extension agencies.

\section{References}

[1] Anonymous, 2013. Indian Horticulture Database. www.nhb.gov.in

[2] Aski, S. G., Gotyal, S. H., Angadi, J. G. and Gouder, L. V. H. 2013. Constraints and suggestions of beneficiaries of KVKs in adoption of recent technologies. Plant Archives. 13: 339-344.

[3] Mahadik, R. P., Mehta, P. G. and Patil, V. G. 2008. Adoption of recommended mango cultivation technology by mango growers. Karnataka Journal of Agricultural Sciences. 21(2): 314-315.

[4] Sumathi, P. and Rathakrishnan, T. 2008. Adoption of improved practices in mango cultivation by small and big farmers in Dharmapuri district. Madras Agricultural Journal. 95 (1-6): 239-241.

[5] Yadav, R. N., Dutt, T., Singh, D. and Singh, V. K. 2010. Constraints faced by mango orchardists and suitable strategy for promotion of quality mango production. Progressive Agriculture. 10(1): 106- 110. 